\title{
Edmund Husserl: Phantasy, Image Consciousness, and Memory (1898-1925)
}

\section{Translated by John B. Brough (Edmund Husserl, Collected Works, vol. XI), Dordrecht: Springer, 2005, 723 pp, ISBN-101-4020-2641-2 (HB)}

\section{Eduard Marbach}

Published online: 1 August 2012

(C) Springer Science+Business Media B.V. 2012

Arguably one of the most astonishing abilities of human beings is our capacity to refer to and to occupy ourselves with things, people, events and states of affairs that are not at all actually present here and now. We do so in our private thoughts, in imagining, remembering, planning, or publicly by means of images, plays, languages and other sign systems. In all such activities we normally understand without especially having to reflect that we do not simply perceive something present with our senses, but that in one way or another we have something as it were in view or in mind that is not itself present. At the same time, while knowing that we are occupied with something that we do not take to be really present, it nonetheless feels like we are standing in the actuality here and now. Even what we merely present in thought as not at all itself being really present here and now, or what we likewise experience as being represented in an image, as played, described, or otherwise signified, is given to us only in contrast to that which counts as being really present. If we were to lose this consciousness of contrast, we would be dreaming, or be subject to an illusion or hallucination, and in the process we would take the things, people, events and states of affairs to which we would be turned to be really given-instead of taking them to be merely imagined, remembered, or to be presented as merely possible, as represented in an image, in a symbolic play, or verbally, and so on.

In short, we human beings do not only live in the present, perceiving it with our senses, we are also able, in manifold ways, to transcend the always present sensory actuality and to be active in one or another form of re-presentation (Vergegenwärtigung). In his lectures of 1904/1905, the third main piece of which on "Phantasy and Image Consciousness" makes up Text No. 1 of Phantasy, Image Consciousness, and Memory, Husserl says:

\section{E. Marbach ( $\square)$}

Institut für Philosophie, Universität Bern, Länggassstrasse 49a, Bern 9, Switzerland

e-mail: eduard.marbach@philo.unibe.ch 
Everyone knows what it means to re-present an object to oneself, to bring it forward in an internal image, to make it hover before one. Everyone uses the expression "to imagine" [einbilden], and thus knows to some extent what is essential to the case. But only implicitly, I am sorry to say (Hua XXIII, p. 17/18).

The point of the texts in the volume of Edmund Husserl's Collected Works ${ }^{1}$ here reviewed is primarily to clarify, by way of reflective analyses of consciousness, diverse phenomena of re-presenting (Vergegenwärtigen) as against perceiving. ${ }^{2}$ In a wide usage of the term, Husserl often understands phantasy (memory included) quite generally as "consciousness characterized as re-presentation (Vergegenwärtigung)" (Hua X, p. 45/47); he also says:

Consciousness of what is not present [Nichtgegenwärtigkeits-Bewusstsein] belongs to the essence of phantasy. We live in a present; we have a perceptual field of regard. In addition, however, we have appearances that present something not present lying entirely outside this field of regard (Hua XXIII, p. 58f./63).

The texts in Phantasy, Image Consciousness, and Memory pertain to a topic that had been central for Husserl from early on, namely to elaborate for given species of experiences the typically phenomenological definition of essentially different modes of consciousness, that is, of the intentional relation to something objective. More precisely, in the texts of this volume it is a matter of determining within the class of presentations (Vorstellungen) - in contrast to the classes of judgments and emotions-the specifically different characters of the intention of the intuitive (anschauliche) presentations in contrast to conceptual (begriffliche) presentations. One of the chief tasks for the analysis of the domain of intuitive mental acts consists in setting off the diverse forms of intuitive re-presentations (anschauliche Vergegenwärtigungen)—perhaps better "representifications"-from the basic form of intuitive consciousness, namely, perception or presentification (Gegenwärtigung), by bringing into relief the intentional characteristics of these various forms.

It is generally characteristic of intuitive presentations that in them an object appears (erscheint), and this is either the presented object itself (selbst) or an image (Bild) of the latter. This stands in contrast to the consciousness of signification (Bedeutungsbewusstsein), in which an object or a state of affairs is meant or signified (gemeint), without having to appear. It can only be mentioned here that for Husserl all these investigations into the forms of intuitive and conceptual or significational presentations stand in a foundational connection. It was Husserl's view from early on that the higher-level conceptual and categorial acts of meaning, signification and judgment, in which cognition comes to pregnant expression, are founded in the sensuous, intuitive acts of perception and their modifications. The

\footnotetext{
${ }^{1}$ Originally published from the handwritten, mostly shorthand Nachlass in German as Hua XXIII. Throughout this review, references to this volume and its translation will be given as Hua XXIII followed first by the German pagination and then the English pagination, separated by a slash.

${ }^{2}$ Parts of the text of this review are taken over and translated into English from my „Einleitung des Herausgebers“ in Hua XXIII and from my „Einleitung“ to Husserl (2006).
} 
analysis of these intuitive acts and their intellective structuring is crucially involved in Husserl's studies on the theory of meaning and judgment. ${ }^{3}$

In his philosophical phenomenology, as is well known, Husserl argued that prior to all causal-explanatory, psychological, and (increasingly nowadays) cognitive and affective neuroscientific investigations of our experiential life and actions, the phenomena themselves as they occur in our conscious life are to be subjected to a differential analysis. This is the task of "a description not at all appreciated for its true importance and difficulty" (Hua XXIII, p. 13/12). Time and again Husserl stressed the difficulties and peculiarities of the reflective descriptive analysis required for doing phenomenology. Descriptively he attempted step-by-step to define the conceptual nature of conscious experiences of distinct kinds on the basis of those inner characteristics that give rise to essential generalizations and thus to concept formations. In Phantasy, Image Consciousness, and Memory, for example, when he starts examining the-at first glance plausible- "notion that phantasy presentation can be interpreted as image presentation" in his lectures of 1904/1905 (Hua XXIII, Nr. 1, §8, note 1, p. 16/note 2, p. 18), he points out:

To begin with, we compare as far as possible the two sorts of imaginings and seek to make clear to ourselves the common element in image presentation. We want to begin gradually and with the greatest possible caution. For as easy as the analysis at first appears, the difficulties that subsequently come to light and gradually require many modifications in what we earlier accepted and many new distinctions in what we earlier took to be simple are just as great (Hua XXIII, p. 17f./19).

And Husserl immediately adds the following general remark:

Indeed, this is universally the peculiarity of phenomenological analysis. Every step forward yields new points of view from which what we have already discovered appears in a new light, so that often enough what we were originally able to take as simple and undivided presents itself as complex and full of distinctions (Hua XXIII, p. 18/19).

It is a philosophically most intriguing and absorbing experience (though no doubt at times a quite frustrating one), when dealing with the shorthand manuscripts from Husserl's Nachlass, that we as readers are able to attend to creative thinking and writing processes in unadorned form, to clarifications gradually reached, but also to their failures and aporias. In a letter of October 1904 to his teacher Franz Brentano, Husserl wrote:

I am certain in advance that a large part of what I have written is erroneous; but equally certain that there were errors that had once to be tried out, once to be ventured. We will not find definite truth in the foundations without having seriously thought through all possibilities. But only he thinks through a possibility wholly seriously who believes in it (quoted in Hua XXIII, p. lii).

\footnotetext{
${ }^{3}$ See, e.g., Hua XL, especially Sect. B. Urteil und Vorstellung, p. 249ff. and Sect. D. Urteil und Anschauung bzw. Wahrnehmung, p. 353ff. Also Husserl (1954).
} 
Such a putting to the test of possibilities is typical of Husserl's "analytic phenomenology" (Hua XIX/1, p. 17) and it is also very much at work in Phantasy, Image Consciousness, and Memory. Both understanding and evaluating the argumentation in these texts require a high degree of reconstructive thinking. In the course of this enactment it is not only a matter of checking the logical consequences among the statements. In order to assess their veracity it is also necessary that one perform for oneself reflective observation of the objects of phenomenological analyses, that is, of the phenomena of consciousness with which the statements are concerned and which are exemplified by means of suitable instances.

John B. Brough's admirable translation into English of all of Husserl's texts and appendices of the German edition of Husserliana XXIII is a most generous gift to the philosophical community worldwide. The translation is also valuable to readers able to understand the German originals. Judging from this reviewer's case, it can indeed be an illuminating experience for a native German speaker somewhat familiar with Husserl's often highly convoluted texts to reacquaint himself or herself with Husserl's exploratory thinking when it is made available in such a wellconsidered translation. Brough had already produced a highly acclaimed translation into English of Husserl's demanding texts On the Phenomenology of the Consciousness of Internal Time (1893-1917), first published 1990 as volume IV in Edmund Husserl. Collected Works, and accompanied it with a very informative and philosophically challenging introduction. His Husserl expertise, already evident there, is borne out again in Brough's new translation and in his impressive "Translator's Introduction" to Phantasy, Image Consciousness, and Memory, in which he discusses a number of issues also addressed below. Far beyond the narrow circle of Husserl scholars, students of the philosophically closely related topics treated in Husserl's texts should count themselves lucky to have them made available in such excellent translation. I cannot help but wonder what, for example, Colin McGinn's fine study, Mindsight. Image, Dream, Meaning (2004), might have become if the author had already known of Brough's translation, published one year later. Perhaps it would have prompted McGinn to draw on Husserl's analyses and include him among the "philosophers as diverse as Sartre, Wittgenstein, and Collingwood" who, "in the twentieth century [...] paid extensive attention to imagination" (McGinn 2004, p. 1)!

In the "Einleitung des Herausgebers" to Hua XXIII I provided an account of the history of Husserl's texts in the volume, of the historical origin of the phenomenology of intuitions (Anschauungen), and in particular of the development of problems in Husserl's phenomenology of intuitive re-presentations (representifications) (Hua XXIII, pp. Xxv-lxxxi). Within the limits of the present review, let me seize the opportunity of singling out two problem areas which, even after more than thirty years, strike me as being among Husserl's philosophically most interesting contributions to consciousness studies, the analytical subtlety of which can be gathered from this collection of texts.

With an eye on Husserl's development after his lectures on phantasy and image consciousness of 1904/1905, it is indeed very intriguing to see that some of the main results with which Husserl seemed to be happy at the end of the lectures were quite 
radically put into question by himself shortly afterwards and were gradually and substantially refined in later texts included in Phantasy, Image Consciousness, and Memory. The analytical distinction between two forms of presentation-phantasy and image consciousness-provides, I think, a lasting gain of insight into the phenomenological situation, undercutting the initially assumed parallelism of phantasy and image consciousness which took them both to be an image presentation (Bildlichkeitsvorstellung). This is not the case, however, either (1) with regard to the determination of the phantasy presentation in itself and as such, or (2) with regard to the determination of the image presentation in itself and as such.

Regarding (1), the phenomenology of phantasy: Towards the end of his analysis in 1904/1905, after decisively arguing in favor of "the essential distinction between imagination (Imagination) in the proper sense (perceptual imagination), and imagination understood as phantasy (Phantasie)" (Hua XXIII, Chap. 8, p. 82ff/ 89ff.), Husserl concludes: "The phantasy appearance, the simple phantasy appearance unencumbered by any imaging built on it, relates to its object just as straightforwardly [einfältig] as perception does" (Hua XXIII, p. 85/92). And especially first with regard to "clear, perfectly adequate phantasies" or memoriesthat is, "without troubling ourselves about obscure phantasies"-he added:

Now it is true of clear phantasies that a pure re-presentational consciousness [reines Vergegenwärtigungsbewusstsein] is brought about in them on the/basis of phantasms and the apprehension objectivating the phantasms. Objectivating the phantasms does not constitute, in advance, an image object that hovers before one and even appears as present; on the contrary, what appears is immediately something that is not present ${ }^{4}[\ldots]$. In itself [...] the phantasy presentation [Phantasievorstellung] does not contain a manifold intention [keine mehrfältige Intention], re-presentation is an ultimate mode of intuitive objectivation [Vergegenwärtigung ist ein letzter Modus intuitiver Vorstellung], just like perceptual objectivation [Wahrnehmungsvorstellung], just like presentation [Gegenwärtigung] (Hua XXIII, p. 85f./92f.- emphasis partly mine).

However, precisely this result will be reversed by Husserl just a few years later. On the basis of a deeper analysis of the phenomena, taking into account internal timeconsciousness, he will elaborate a radically new description of the intentional structure of phantasy as consciousness of re-presentation, with the help of the concept of reproductive modification of experiences. The texts grouped in No. 2, "From the theory of representation [Repräsentation] in phantasy and memory to the introduction of the doctrine of reproduction or double re-presentation [doppelte Vergegenwärtigung]," together with the texts No. 3 through No. 13 and the corresponding appendices, all written between about 1904 up to about 1912 (Hua XXIII, pp. 170-300/207-361), permit us to see into Husserl's search for a more differentiated analysis of pure re-presentational consciousness. The new analysis is then clearly brought to bear in research manuscripts from 1911 and 1912, published

\footnotetext{
${ }^{4}$ Translation slightly amended from "what immediately appears is something that is not present" (p. 93); the German text reads: "das Erscheinende ist unmittelbar das Nichtgegenwärtige" (p. 86).
} 
in the volume as Nos. 14, 15 and 16 and corresponding appendices (Hua XXIII, pp. 301-485/363-579).

To illustrate this achievement of clarification in Husserl's analyses of the consciousness of re-presentation, consider for example the following passages: "Hence we must say: Every experience admits of a fundamental modification. It is called the reproductive modification, and in relation to it the unmodified experience itself is called impressional experience" (Hua XXIII, p. 330/402), explicated in a note thus:

Internal consciousness is impression in relation to every experience: every experience is impressional. Every reproductive modification is the reproduction of an internally "impressionally conscious" experience; the reproduction itself is impressionally conscious (Hua XXIII, p. 330, note 3/p. 402, note 4). ${ }^{5}$

This new description is based on analyses of internal time-consciousness, which Husserl began to study seriously in the last part of the lectures of 1904/1905. At the outset of this part, after referring to "the most peculiar difficulties, contradictions, and confusions" in which one gets entangled as soon as one attempts to give an account of time-consciousness, Husserl had pointed to "the most intimate connection" between the intuitive acts of perception, imagination, memory, and image consciousness, which had been dealt with in the previous parts of the lectures, explaining in this deleted passage that

it is obvious that an analysis of the consciousness of perception, the consciousness of phantasy, memory, expectation is not accomplished as long as temporality [Zeitlichkeit] is not also included in the analysis, and that conversely an analysis of time-consciousness presupposes to a large extent that of the said acts (Hua X, editorial supplement, p. 394).

If not at once, then in the course of only a few years, when he turned to the "clarification of diverse basic kinds of the modification as well as of all kinds of 're-presentation'," Husserl elaborated an ever more refined insight into the "most remarkable intentionality of the "modifications'." 6 The main result clearly contradicts the finding from 1904/1905 where Husserl had stated that "in itself" (an sich selbst), phantasy does not contain "a manifold intention" (keine mehrfältige Intention). A few years later, in contrast, Husserl was able to pinpoint the description of the re-presentational modification, which he came to see as itself "an event belonging to internal consciousness" (Hua X, p. 368/379) or to timeconsciousness as follows:

[...] every 'modification' $<$ is $>$ characterized thus that in it itself the relation to another consciousness is contained of which it is called modification, a

\footnotetext{
5 Translation partly amended from "is the reproduction of an experience of which there is "impressional consciousness' internally; there is impressional consciousness of the reproduction itself” (p. 402, note 4). The German text reads: "ist Reproduktion eines innerlich 'impressiv bewussten' Erlebnisses, die Reproduktion selbst ist impressiv bewusst" (p. 330, note 3).

${ }^{6}$ Quoted in Hua XXIII, p. 1xiii; see also p. 1xx. Subsequently the entire manuscript from 1917/1918 was published in Hua XXXIII, Text Nr. 9. The quote is found there on p. 176.
} 
consciousness, which is not really contained in it and yet is graspable for a suitably directed reflection. [...] And with it are then still connected specific reflections on the corresponding act-correlates. ${ }^{7}$

Henceforth, what Husserl will emphasize in his analyses of the main types of re-presentational acts is their "wondrously interwoven intentionality" (wundersam ineinandergeflochtene Intentionalität; see Hua VIII, p. 128; emphasis partly mine). A remarkably two-sided version of this subtle result is already described in a text from 1911 or 1912 with regard to the example of memory, which is included in Husserl's wide concept of phantasy as re-presentation. On the one side:

Memory is a reproductive modification of perception, but it has the remarkable peculiarity that it is also re-presentation of perception and not simply re-presentation of what was perceived. I remember lunch. "Implicit" in this memory, however, is also memory of the perception of lunch (irrespective of the direction of my act of meaning) (Hua XXIII, no. 14, p. 305f./367; emphasis mine).

And on the other side, a little later in the same text:

The external perception is perception. And if the modification of the perception is then a corresponding memory, we have the remarkable circumstance that the corresponding memory is not only memory of the perception but that the modification of the perception is also memory of what was perceived (Hua XXIII, p. 308/370; emphasis mine).

Texts like these clearly show Husserl's discovery of the duality (Doppelheit) in the re-presentational consciousness itself and in its intentional relation to something objective, respectively. This duality is involved in the essence of the reproduction as reproduction of an impression, and it requires a double-sided reflective description, directed (a) at the re-presented object (e.g., lunch) and (b) at the re-presentednamely reproductively modified or intentionally implied-perception, i.e., the experience that is "contained" in a re-presentational act.

Moreover, Husserl recognizes that description of the "modes of reproduction" must also take into account the phenomena of position takings (Stellungnahmen), cognitive acts that are expressed in judgments as well as affective position takings, aesthetic evaluations, etc. Such phenomena reach beyond the domain of the intuitive re-presentations belonging to phantasy, image consciousness and memory and lead into the domain of the theory of judgment, of "suppositions" (Ansätze) and modifications of merely thinking-of. All these developments and descriptive refinements are based on the theory of the reproductive modification or the intentional implication of consciousness and confirm the general point that what, in phenomenological analysis, could originally be taken "as simple and undivided presents itself as complex and full of distinctions."

Regarding (2), the phenomenology of image consciousness: In approaching this topic-to which, as Brough also observes in his "Translator's Introduction," "some

\footnotetext{
7 See note 6. The quote is from Hua XXIII, p. lxx, or Hua XXXIII, p. 176; emphasis mine.
} 
of Husserl's most fascinating and cogent analyses are devoted" (p. xliv)—it strikes me as particularly important to emphasize that the seemingly achieved clarity in the analysis of ordinary image consciousness in the lectures of 1904/1905 is repeatedly put into question in later texts. In the course of the lectures, "intent on distinguishing between phantasy presentation and ordinary image presentation," Husserl confidently states: "Image presentation became perfectly clear to us" (Hua XXIII, p. 54/59, emphasis mine). For he once more insists that:

One thing is indeed clear from the beginning: The "image" in the case of physical imaging - that is, the image object-is a figment, a perceptual object but also a semblance object. It appears in the way in which an actual physical thing appears, but in conflict with the actual present that conflict-free perception brings about. Now this figment, or rather this fiction consciousness, is permeated with representational consciousness [Bewusstsein der Repräsentation]. Hence imaginative consciousness arises here. And it arises in the new conflict between the figment and what is imagined (Hua XXIII, p. 54, similarly p. $79 / 59$ and $85 f$.).

The really moot point in Husserl's analyses of image consciousness concerns the mode of givenness of the image object. When he, in his early investigations, says things to the effect that "the image object appears in the midst of perceptual reality and claims, as it were, to have objective reality in its midst" (Hua XXIII, p. 47f./51), or when he describes this way of givenness as "an image object appearing as present [...] an object that deports itself as a member of the objectivity of one's field of regard" (Hua XXIII, p. 83/90), or as "a figment, a perceptual object but also a semblance object" (Hua XXIII, p. 54/59), then at least at first glance it may look as if Husserl argued that imaging (Bildlichkeit) were at bottom constituted as consciousness of a figment in the sense of an illusion - as if, conflicting with other perceptual positings at the level of perception, the image figment (Bildfiktum) turned out to be a mere semblance, "a nothing" (Hua XXIII, p. 46/50), though still as a presently appearing perceptual object, analogously to a "sensuous semblance" (Hua XXIII, p. 32/33).

Contrary to such a view that lets image consciousness appear to be a matter of sensuous perception and conflicts among perceptual positings alone, there are, however, several passages already in the lectures of 1904/1905, where Husserl clearly argues that for image consciousness to come about, a consciousness of representation (Vergegenwärtigungsbewusstsein) is fundamental, thanks to which the relation to the image subject is constituted. Thus, for example, with regard to ordinary image consciousness:

If the conscious relation to something depicted is not given with the image, then we certainly do not have an image. This conscious relation, however, is given through that specific consciousness belonging to the re-presentation of what does not appear in what does appear [...] If two objectivating apprehensions were not interwoven with one another, it would be a miracle, or nonsense, how a consciousness of this kind is possible, since only the image and certainly not the subject falls into the appearance. The making intuitive in 
the image, which in the image-appearing possesses the consciousness of the image subject, is not an arbitrary characteristic that adheres to the image. Rather, the intuition of the image object awakens precisely a new consciousness, a presentation of a new object $[\ldots / . .$.$] Yet this new presentation does not$ lie next to the presentation of the image object either; on the contrary, it coincides with it, permeates it, and in this permeation gives it the characteristic of the image object (Hua XXIII, p. 31/32f., emphasis partly mine).

Here and elsewhere in the early lectures, Husserl emphasizes that "phantasy consciousness," i.e., consciousness of re-presentation, "makes up the most essential moment even in common imaging" (Hua XXIII, p. 87/93f.). This consciousness of re-presentation or phantasy, in contrast to "the pure and simple phantasy function" (p. 94, line 35-reading "phantasy function" instead of "phantasy object"), "is, however, permeated with a presentational consciousness" (Hua XXIII, p. 86/93), and this permeation bestows in effect the "characteristic of unreality" (Unwirklichkeit) (Hua XXIII, p. 47/51), i.e., the "characteristic of the image object" (Hua XXIII, p. 31/33) upon that which perceptually appears, however not the characteristic of an annulled and illusory semblance object.

That the consciousness of semblance or of unreality in the case of an image can indeed not be understood as a figment consciousness in the sense of an illusion is made even clearer in later texts from about 1912 (Hua XXIII, Nr. 17, p. 486ff./No. 17, 581ff.). Husserl now explains that the characteristic of unreality in the case of an image rests on the circumstance that something is projected into reality from phantasy (hineinphantasiert), something that is not at all given in the immediately, perceptually appearing present. The image does not genuinely " "appear" in the unity of reality, "but in its own space, which in itself has no direct relation to real space" (Hua XXIII, p. 480/570). The image figment does appear "without having the characteristic of reality, without 'laying claim' to reality, a claim that would first have to be cancelled" (Hua XXIII, p. 480/571—reading "first" instead of "only"). As Husserl describes it in the present context, the difference between phantasy and image consciousness

consists only in the fact that the "phantasy image" is a reproductive image, the seen image a perceptual [perzeptives] image. Both are cases of imagination. This must never be forgotten and is absolutely certain. I was entirely correct when I sought again and again to take image apprehension as imagining [Imagination]. It is imagining. The image turns into something null only through a connection with reality. As soon as I take it in this connection (or take it as having this connection; for example, take the image subject, where the frame begins, in spatial relation to real space, and so on) - as soon as I thus suppose it-it turns into something null (Hua XXIII, p. 480/570).

As already hinted, the truly puzzling and at the same time philosophically particularly challenging aspect of Husserl's analysis of image consciousness, variably pursued over many years, concerns his wavering views of the mode of givenness (Gegebenheitsweise) of the image object. It is an elating experience to 
think through all the nuances of the relevant texts in Brough's excellent translation. Not only in the early texts, but still, for example, in No. 18, probably from 1918, Husserl presents the situation as if the image object were a perceptual givenness which stands there "as present actuality." But "this present and this actuality," he then remarks, is "just actuality as if," adding "the image only hovers before us perceptually" (Hua XXIII, No. 18, p. 506/607). And in No. 20, written in the first half of the nineteen-twenties, where Husserl discusses the concept of phantasy in relation to the universal concept of neutrality and "mere presentation," with brief references to Aristotle, Hume, and Brentano, as well as to his own Logical Investigations (1901) and Ideas (1913), there is this passage:

"Mere" phantasy signifies, then, that no "actual" ["wirklicher"] performing of an act takes place- "mere presentation". But matters no doubt become more complicated in the case of the "image object", which, appearing as present "in person" [leibhaftig], can nevertheless also be designated as "fiction", though one must no longer speak of a re-presentation [Vergegenwärtigung] in this case. Indeed, it is presentation [Präsentation]. Here, too, the "positing", the believing in something [das In-Geltung-Haben], is "missing" (Hua XXIII, No. 20, p. 575/693; see also No. 20, p. 580/697f.).

Then again, in No. 16, probably from spring 1912, Husserl notes with regard to image consciousness:

Must we not say: "Exhibiting" ["Darstellung"] belongs to the essence of image consciousness; image consciousness is not simply perceptual consciousness and, in any event, not a perceptual consciousness that is combined additionally with a reproductive consciousness (namely, a phantasy consciousness)? That is not correct (Hua XXIII, p. 471/560). ${ }^{8}$

Starting the analysis anew, Husserl continues:

Image consciousness has implicated in it "sensation contents" that one can find in it, that one can grasp in it, and doubtlessly it has this in common with perceptual consciousness. However, if we focus our attention strictly on the image appearances in which these trees, these human beings, and so on, appear as image trees, image human beings, we find, as we do in the case of reproductive phantasy, that the appearances are obviously not merely perceiving appearances. On the contrary, they are imagining appearances: that is to say, the sensation content in the appearance exhibits something, and the appearance itself exhibits appearance. The apprehension is not simply apprehension, but the exhibiting of apprehension (Hua XXIII, No. 16, p. 471f./560f.).

Pondering upon several other possibilities of understanding the status of the image object in image consciousness in the same text, Husserl also offers the following

\footnotetext{
${ }^{8}$ The translator's note is to the point when he observes that "Husserl seems to mean here that it would not be correct to say that image consciousness is simply perceptual consciousness, etc." (p. 560, note 6).
} 
self-criticism of his former view developed in the lectures of 1904/1905, noting that "these are important [folgenschwere] questions":

The distinctions I have been studying here, though perhaps I have not yet given them a perfectly accurate interpretation, ought not to confuse us. We can understand by image object the actually perceived [...] object as opposed to the object exhibited. If we look more closely, however, we have distinctions in connection with images. My example of Raphael's theological painting 9 : The little grey cherubs, the small female figure-I called these little figures image objects. What is exhibited, the subject, is the form of a sublime woman, and so on. If we look more closely, however, the following view offers itself: The little figures are indeed exhibited objects (Hua XXIII, p. 473/562). ${ }^{10}$

All of these considerations result in a number of conceptual clarifications in the text from 1912:

In summary, therefore: (1) We must separate the apprehension of an image object and the consciousness of a perceptual illusion <inserted later: "(something null)" $>$. The former is nonpositing, the latter positing. (2) In union with the image-object apprehension we have the exhibiting (Darstellung). [...] Now exhibiting as exhibiting has certain things in common with reproduction <i.e. with re-presentation $>,[\ldots]$ (5) [...] namely, precisely the fact that we have in every component of the exhibiting (of the genuine exhibiting) a reference to "something corresponding" (Hua XXIII, p. 474f./563ff.).

In concluding his many reflections about modes of reproduction, phantasy, image consciousness with simultaneous consideration of the phenomena of position-taking and abstaining from it in the texts no. 15 and no. 16 and the related appendices, Husserl emphasizes:

We must therefore universalize the concept of phantasy (let us say, the concept of re-presentation). There are two fundamental forms of re-presentation:

(1) reproductive re-presentation;

(2) perceptual re-presentation, that is, re-presentation in image, in pictorial exhibiting. Since reproductive modifications correspond to every experience, the perceptual re-presentation then also enters into reproductive re-presentation, there arises pictorializing re-presentation in the phantasy re-presentation (or in memory). ${ }^{11}$

\footnotetext{
9 See Text No. 1, §21, p. 47: "For example, if I contemplate the picture of Raphael's theological subject hanging above my desk [...]." Husserl writes "Bild der Raffaelschen Theologie" (Hua XXIII, p. 44), referring to Raphael's painting "Theologia”.

10 "Exhibited" in the last sentence was somewhat later changed to "merely presented" (bloss vorgestellte), to be understood as re-presented (vergegenwärtigt) (ibid.).

11 Translation partly amended: "enters into" instead of "passes into," and "there arises" instead of "grows into." Both changes seem to me better to convey Husserl's point, namely that perceptual representation, i.e. image consciousness, can also be reproductively modified, yielding a more complex reproductive re-presentation of a perceptual re-presentation-for example, a phantasy or a memory representation of a re-presentation in image, as in everyday cases of phantasying of seeing, or remembering of having seen, a picture.
} 
One must separate these modifications from those that convert positing into nonpositing. (Intersection of the two kinds of distinction.) Furthermore, one must not confuse nonpositing perceptions with experiences that exhibit something in an image: with re-presentation, therefore (Hua XXIII, p. 475f./ $565)$.

To round off the review of John B. Brough's translation, permit me to propose a more unified English terminology for some of the basic German terms in Husserl's writings on the topics at hand. The German term "Vorstellung" is notoriously ambiguous, as is no doubt "representation" in English. Unlike what I myself have practised in Marbach (1993) and elsewhere-for example, in the Encyclopedia of Phenomenology (Embree et al. 1997, p. 603ff.), under the heading "re-presentation," and unlike the translator of the volume under review, I would now like to suggest, taking a clue from Nicolas de Warren's recent paper "Tamino's Eyes, Pamina's Gaze" (2010), the following terminology as perhaps the least confusing:

\begin{tabular}{ll}
\hline Vorstellung, vorstellen & presentation, to present \\
Gegenwärtigung, gegenwärtigen & presentification, to presentify $(\mathrm{NdW})$ \\
Vergegenwärtigung, vergegenwärtigen & representification, to representify $(\mathrm{NdW})$ \\
Darstellung, darstellen & representation, to represent \\
Phantasie & phantasy or imagination \\
\hline
\end{tabular}

As I presently see it, this would take care quite elegantly of the various semantic nuances and one could even avoid hyphens, which disappear in any case all too often when a word has to be separated.

To be sure, I am fully aware of the practical difficulties of making such a proposal universally acceptable. And let us not forget that terminology is just terminology; the most important thing is conceptual lucidity, and Brough's translation of Husserl's terminologically often bewildering texts testify to his masterly handling of them at the conceptual, properly philosophical, level.

\section{References}

De Warren, N. (2010). Tamino's eyes, Pamina's gaze. In C. Ierna, H. Jacobs, \& F. Mattens (Eds.), Philosophy, phenomenology, sciences, Phaenomenologica 200 (pp. 303-332). Dordrecht: Springer.

Embree, L., et al. (Eds.). (1997). Encyclopedia of phenomenology. Dordrecht: Kluwer.

Hua VIII. Husserl, E. (1959). Erste Philosophie (1923/24). Zweiter Teil: Theorie der phänomenologischen Reduktion. R. Boehm (Ed.). Den Haag: Martinus Nijhoff.

Hua X. Husserl, E. (1966). Zur Phänomenologie des inneren Zeitbewusstseins (1893-1917). R. Boehm (Ed.). Den Haag: Martinus Nijhoff; On the phenomenology of the consciousness of internal time (1893-1917). J. Brough (Trans.). Dordrecht: Kluwer Academic Publishers, 1991.

Hua XIX/1. Husserl, E. (1984). Logische Untersuchungen. Zweiter Band, Erster Teil. Untersuchungen zur Phänomenologie und Theorie der Erkenntnis. U. Panzer (Ed.). The Hague: Martinus Nijhoff.

Hua XXIII. Husserl, E. (1980). Phantasie, Bildbewusstsein, Erinnerung. Zur Phänomenologie der anschaulichen Vergegenwärtigungen. Texte aus dem Nachlass (1898-1925). E. Marbach (Ed.). The Hague: Martinus Nijhoff. 
Hua XXXIII. Husserl, E. (2001). Die Bernauer Manuskripte über das Zeitbewusstsein (1917/1918). R. Bernet and D. Lohmar (Eds.). The Hague: Martinus Nijhoff.

Hua XL. Husserl, E. (2009). Untersuchungen zur Urteilstheorie. Texte aus dem Nachlass (1893-1918). R. D. Rollinger (Ed.). Dordrecht: Springer.

Husserl, E. (1954). Erfahrung und Urteil: Untersuchungen zur Genealogie der Logik. L. Landgrebe (Ed.). Hamburg: Felix Meiner Verlag; Experience and judgment: Investigations in a genealogy of logic. J. S. Churchill and K. Ameriks (Trans.). Evanston: Northwestern University Press, 1973.

Husserl, E. (2006). Phantasie und Bildbewusstsein, Studienausgabe. Text nach Husserliana Band XXIII. E. Marbach (Ed.). Philosophische Bibliothek Band 576. Hamburg: Felix Meiner Verlag.

Marbach, E. (1993). Mental representation and consciousness. Towards a phenomenological theory of representation and reference. Dordrecht: Kluwer.

McGinn, C. (2004). Mindsight. Image, dream, meaning. Cambridge, MA: Harvard University Press. 